\title{
El sermón, la folletería y la ampliación del mundo editorial mexicano, 1810-1854
}

\author{
Brian F. Connaughton \\ UAM-IZTAPALAPA
}

\author{
Reseña la evolución que siguieron los sermones \\ en el escenario de los impresos mexicanos del siglo xIx \\ destacando que perdieron su importancia numérica, \\ transformando su discurso al acentuar sus \\ preocupaciones cívicas y al tener que "convencer" \\ y no sólo adoctrinar a la opinión pública.
}

$A$ ntes de 1821 el sermón mexicano había asumido ya un marcado tono político. Los predicadores habían tenido ocasión de pronunciarse sobre la rebelión, la ciencia moderna y el papel del clero y la Iglesia en la vida del país. En los años subsecuentes los oradores eclesiásticosse definieron acerca de la independencia y la ascensión de Agustín de Iturbide al poder $\mathrm{y}$, en las décadas siguientes, se dedicarian a monitorear el progreso y la estabilidad de la nación al dar ésta sus primeros pasos autónomos. Como la impugnación del papel protagónico del clero en la sociedad aumentaba de tono, el sermón frecuentemente reflejaba la defensa velada o confesa de la posición contraria. Igualmente, esta prédica eclesiástica, normalmente asociada en sus orígenes con un paréntesis de reflexión durante el oficio de la misa, se ocupaba de la correcta interpretación del dogma y de las prácticas sancionadas de la piedad religiosa.

Mas el sermón ya no era el género predilecto de la industria editorial del país, despúes de la literatura de novenas y devoción, como lo había siclo en 
la época colonial. ${ }^{1}$ La expansión de una variada publicación de folletería, de libros y de periódicos hizo que el sermón perdiera su lugar, largamente sostenido, en el centro de la producción editorial mexicana. Surgía a su lado, muy cercana en nuestra opinión pero con fines patrióticos de nuevo cuño, la oración cívica o el discurso patriótico. También se multiplicaron los discursos académicos y los actos de premiación educativa. Pero quizá lo que más destaca es la avasalladora presencia de una folletería política que pretendía fijar rumbos a la patria. La activa presencia de clérigos en esta folletería es clara, si bien difícil de cuantificar. También lo fue su participación en el periodismo, singular pero no exclusivamente en el Defensor de la Religión, producto este último del combativo clero jalisciense. Sin embargo, creo que el sermón decimonónico no sólo compite con la vastedad de publicaciones de folletería y periodismo, sino que, dentro de la Iglesia, es ensombrecido parcialmente por la presencia protagónica de la pastoral episcopal, que pretende marcar con la mayor claridad, y sobre todo con plena autoridad, lo que deben ser las conductas y las creencias de la feligresía mexicana en medio de los retos de su vida moderna.

Mayormente de lenguaje directo y con una pulcra relación de notas al pie de la página, los sermones decimonónicos demuestran un clero preocupado por la claridad de expresión, las

1 Compárese esto con lo asentado por Herrejón, "Oratoria", 1994, pp. 57-92. ideas bien definidas y la aplicación de criterios racionales a partir de los misterios de la fe. Los sermones evidencian un interés por la vivencia social en común, o cosa pública, desde la perspectiva religiosa y moral. No deben verse simplemente como contrincantes del discurso eminentemente cívico, sino, cuando menos, como parcialmente hermanados con él. En esta óptica, no deja de ser significativa la consolidación de una tendencia ya acentuada antes de la independencia, de predominio del predicador del clero secular, o del siglo, sobre el clero regular. No obstante, corría paralelo con su preocupación cívica un claro deseo de impedir la laicización de la vida pública y de aunar a los progresos del siglo un definido perfil de convicción religiosa. ${ }^{2}$

Aún parece viable sostener, como lo hicimos hace varios años, que el sermón-por contraste con el edicto y la carta pastoral emitidos generalmente bajo la autoridad episcopal- poseía cierto carácter polémico-especulativo que no obligaba a la feligresía de inanera categórica. En su interpretación de la doctrina de la Iglesia en algún punto dogmático o de disciplina, coyunturalmente aludía con fuerza a cuestiones relevantes de la vida pública de la sociedad, fijando "un marco de referencia religioso para los asuntos mundanos". Es válido asentar que fraguaba un "contradiscurso o metadiscurso sobre el discurso secular". Destacan, como autores de sermones, prominentes personalidades eclesiás-

2 Ibid., 1994, pp. $72-73$. 
ticas, infrecuentemente obispos, pero comúnmente canónigos, así como curas y frailes de mérito y posición. ${ }^{3}$

La elaboración de un discurso que polemizaba con las corrientes seculares de la época, demuestra otro aspecto importante del sermón de la época: no sólo había perdido figuración numérica en la producción editorial del país, sino que había perdido su papel de aglutinante de lealtades y eje de las celebraciones públicas. La voz eclesiástica que se proyectaba a través del sermón no tenía garantizada de antemano su legitimidad ante el público. El sermón decimonónico no sólo tenía que exaltar el espíritu religioso, o instruir a la grey en los dogmas de la fe, tenía que convencer a la opinión pública. Mas era ésta una situación incómoda y, en el fondo, inaceptable para el clero. Un recurso común del orador eclesiástico era pretender no ser un simple contrincante en la polémica discursiva de la época, sino instrumento de la dirección de la sociedad hacia fines trascendentes, sin mácula y no sujetos a interpolaciones de la mente secular.

El desplazamiento del sermón del centro del escenario público, no se dio sin embargo, de una sola vez. Fue gradual, y esto se nota en el variable tono que se refleja en los sermonarios de años distintos. La concentración mayor de sermones en los años veinte se da en 1821 y 1822 , y los caracteriza su optimismo, acorde con el espíritu de la época y las seguridades de que gozaba el clero dentro de la fórmu-

3 Jaleología, 1992, pp. 145-147. la política iturbidista. ${ }^{4}$ Para los años treinta, los sermones empiezan a demostrar empero preocupación, cuando no pesimismo. Se asoma la pretensión de resacralizar la cosa pública en medio de una percepción de pérdida de valores, de agresión contra el catolicismo y su clero, y de zozobra generalizada. En los años cuarenta, los sermones proyectan muchas veces un espíritu de moderación, en momentos en que había esfuerzos políticos notables por lograr un consenso de valores, recuperando una parte-pero no todo- del espíritu liberal que fue sacrificado a mediados de los años treinta. Para los años cincuenta, sin embargo, se asoma en los sermones una notable inquietud por la búsqueda -nacida de la decepción- de soluciones a los problemas funcionales del pais. También hay un marcado retorno, en el sermón impreso, a temas religiosos que apuntan al carácter milagroso y trascendente de la vivencia de la fe.

Durante todo este tiempo pervivió el género guadalupano del sermón, invariablemente asociado con una fuerte corriente providencialista que permeaba en general el discurso, tanto religioso como cívico. En 1836, un sermón reconocía a la Virgen de Guadalupe como el fundamento de la nación mexicana y de su futuro, verdadero valladar ante el escepticismo corrosivo que se asomaba ante "todo lo sobrenatural". 5 215.

"González, "Optimismo", 1948, pp. 155.

5 Gutiérrez, Sermón, 1836, p. 1. 
Como se demostró en 1839 después del conflicto bélico con los franceses, el sermón podía tambiến usarse para desvanecer falsos antagonismos entre la Iglesia y la forma republicana de gobierno. Un orador planteaba que los que promovían la visión de confrontación eran "enemigos de la verdadera Iglesia y $[\ldots]$ de la verdadera libertad" ${ }^{6}$ Podía entrar el reimpreso a tales debates públicos sostenidos a través del sermón. Éste fue el caso del sermón que Antonio Joaquín Pérez Martínez había predicado como obispo de Puebla en 1822, mismo que salió a la luz nuevamente en 1839. Allí hablaba de los lazos entre la Iglesia, el Estado, la nación y el progreso, mensaje que se juzgó oportuno reiterar al final de la década de los treinta. ${ }^{7} \mathrm{Se}$ mejantes recordatorios de la convergencia de los valores religiosos y cívicos podían hacerse paralelamente a menciones ocasionales de los peligros inherentes a "un siglo corrompido y seductor", manteniendo así al público consciente de las amenazas existentes a su catolicismo y a la paz social. ${ }^{8}$

Es importante emprender el estudio de la tradicional significación religiosa y cultural, y la simbología de las fiestas religiosas. Representa una parte del conjunto de mensajes codificados en el sermón. Por ejemplo, cuando se celebró la fiesta de la Epifanía en 1843 , el país se hallaba en medio de la reforma constitucional de la república. Un sermón respectivo en la ciudad

${ }^{6}$ Gutiérrez, Sermón, c.1839.

7 Pérez, Sermón, 1839.

${ }^{8}$ Gutiérrez, Oración, 1840. de Puebla, señalaba la importancia de la "fiesta eucarística" para el convenio entre los mexicanos y Dios. En este sentido, se recordaba al público la importancia de no "desprender el orden civil del religioso".?

Hay giros inesperados en los sermones. Cuando Puebla se opuso a la dictadura en 1845 , y venció el sitio del ejército federal, un sermón celebró la derrota del absolutismo por la piedad religiosa. La Virgen de Guadalupe era vista como interviniendo a favor de la "verdadera libertad de la patria", y en oposición a "los avances del más detestable absolutismo". ${ }^{10}$

En los años cuarenta es visible cierta apertura hacia el liberalismo en algunos sermones, como el que se acaba de citar, que en su moderación buscan elementos de un nuevo consenso nacional. La guerra con Estados Unidos ahondaría la tendencia a convocar al pueblo a la unión más allá de las diferencias ideológicas. Luis Gutiérrez del Corral aprovecharía el momento para reafirmar categóricamente el nexo entre la Virgen de Guadalupe y la América mexicana, recalcando la hermandad de los mexicanos en su filial relación con la Virgen. Este autor minimizaba la importancia de las pasadas divisiones intestinas, recalcando el común patriotismo de todos. Señalaba que el "pueblo más amado de su Madre Santísima" se caracterizaba por su compromiso no sólo religioso sino patriótico. ${ }^{11}$ Reclamaba el orador

\footnotetext{
9 Gutiérrez, Sermón, 1843.

10 Isunza, Sermón, 1845, pp. 11-12.

11 Gutiérrez, Sermón, 1846, pp. 7 y 8.
} 
que las instituciones acomodaran todas las opiniones, si no las podian uniformar, apelando al Cielo en la búsqueda de una solución a las disensiones políticas.

Pero es dificil saber en qué medida las tendencias que se hallan en el sermón, o piezas particulares de esta oratoria, eran verdaderamente nacionales, o respondían más bien a matrices de valores y pensamientos regionales. Si comparamos el conjunto de sermones impresos en Guadalajara, ¿replicarán con exactitud los temas, los matices, los tonos y los gustos de los sermones impresos en Puebla, Oaxaca $o$ algún otro punto dotado con imprenta en la república? Las fiestas religiosas que originan sermones impresos, ¿son las mismas en todas partes? La predilección por tal o cual fiesta religiosa o santa patrona, ¿es un fenómeno nacional, o es regionalizada? Desde luego, la virtual hagiografia del general Miguel Barragán o del general Antonio López de Santa Anna, que sale de las imprentas de Guadalajara, no sería de esperar en Puebla. ${ }^{12}$ Por otra parte, no habria de descartarse del análisis del sermón, para fines historiográficos, la presencia de personalidades eclesiásticas fuertes que destacan en una época u otra por el número y el impacto de sus sermones, así como por la composición particular de sus mensajes preferidos.

Si son las preguntas informadas del historiador las que determinan lo que pueden ofrecer los documentos, hay mucho que hacer todavía para que los

12 Espinosa, Oración, 1836; Pablo Antonio, Sermón, 1853. sermones impresos nos confiesen todo lo que traen adentro sobre la historia de este país.

\section{BIBLIOGRAFÍA}

-Espinosa, Francisco, Oración que en las solemnes exequias celebradas en la santa iglesia catedral de Guadalajara por el descanso de la alma del Excmo. Sor. clon Miguel Barragán, general de división en los ejércitos mexicanos y presidente interino de la república dijo el Dr. D. ..., prebendado de la misma santa iglesici el día 11 de abril de 1836, Imprenta del Gobierno a cargo de don Nicolás España, Guadalajara, 1836.

-González y González, Luis, "El optimismo nacionalista como factor de la independencia de México" en Estudios de la historiografĭa americana, El Colegio de México, México, 1948.

-Gutiérrez del Corral, Luis Gonzaga, Sermón histórico-apologético de Nuestra Señora de Guadalupe predicado el día 12 de diciembre de 1833, en la santa iglesia catedral de la Puebla de los Ángeles por el Sr. cura D. ...., hoy interino de Santa Inés Zacatelco, Impreso en la Oficina del Hospital de San Pedro, Puebla, 1836. , Sermón predicado en la solemnidad de los Santos Apóstoles San Pedro y San Pablo el día 29 de junio de 1839 en la santa iglesia catedral de la Puebla de los Ángeles por el señorcura de la parroquia de Señor San José de la misma ciudad Lic. D. ..., Impreso en la Oficina del Gobierno, Puebla, c.1839.

Oración fúnebre que pronunció en la Iglesia del Espíritu Santo de la ciudad de Puebla D. ..., en las honras que hicieron el día 21 de febrero de 1840 el prior y la comunidad de S. Roque a su insigne bienhechor el Sr. Dr. D. Pedro Piñeyro y Osorio, dignidad de tesorero 
que fue de la catedral de la misma ciudad, Imprenta Antigua en el Portal de las Flores, Puebla, 1840. , Sermón de la Epifanía que el día 6 de enero de 1843, predicó en la santa iglesia catedral de Puebla el Sr. cura más antiguo delsagrario D. ..., danlo a la prensa varias personas piadosas, que se interesan en la conservación y pureza de la sagrada religión de Jesucristo, Imprenta Antigua en el Portal de las Flores, Puebla, 1843. Sermón que en la solemne festividad de la Aparición de María Santísima de Guadalupe, día 12 de diciem. bre del corriente año, predicó en la santa iglesia catedral de Puebla el señor licenciado $D$...., canónigo penitenciario de la misma, Imprenta de Atenógenes Castillero en el Portal de Flores, Puebla, 1846.

-Herrejón Peredo, Carlos, "La oratoria en Nueva España", Relaciones, núm. 57, invierno, 1994, pp. 57.92.

-Ideología y sociedad en Guadalajara (1788-1853), CNCA, México, 1992 (Colección Regiones).

-Isunza, José Mariano, Sermón de Nuestra Madre Santísima de Guadalupe, que en la solemne misa celebrada en la santa iglesia catedral el día 12 de febrero de 1845, para dar gracias al Todopoderoso por la gloriosa victoria que obtuvo la benemérita guarnición de Puebla, sitiada en los primeros dias de enero por el numeroso ejército que mandaba el general Santa-Anna, predicó el Lic. D. ..., colegial antiguo del eximio teojurista de $S$. Pablo, individuo del ilustre ynacional de abogados, cura rector del Sagrario, $y$ secretario de cámara y gobierno del Excmo. e Ilmo. Sr. Dr. D. Francisco Pablo Vázquez, dignísimo obispo de esta diócesis y lo publican los Sres. generales y jefes de la guarnición, Imprenta de J. N. del Valle, Puebla, 1845.

-Pablo Antonio del Niño Jesús, Sermón predicado en la santa iglesia catedral de Guadalajara, el día 29 de abril de 1853, con motivo del regreso a la república y de la presidencia del Excmo. Sr. general, benemérito de la patria, $D$. Antonio $L$. de Santa-Anna, por Fr. ..., prior del Carmen, Tipografia del Gobierno, Guadalajara, 1853.

-Pérez Martínez, Antonio Joaquín, Sermón predicado en la santa iglesia metropolitana de México el día 21 de julio de 1822 por el Excmo. e Ilmo. Sr. Dr. D. ..., dignísimo obispo de la Puebla de los Ángeles, con motivo de la solemne coronación del señor D. Agustín de Iturbide, primer emperador constitucional de México, Impreso por Juan N. del Valle, Puebla, 1839. 